\title{
Influence of Weather Parameters on YVMV Incidence of Okra Varieties in Summer Season
}

\author{
Vadla Usha Sree*, B.V. Asewar, A.T. Daunde, A.M. Khobragade and D.S. Perke \\ Department of Agricultural Meteorology, Vasanth Rao Naik Maratwada Krishi Vidhyapeeth, \\ Parbhani-431 402, Maharashtra, India \\ *Corresponding author
}

\begin{tabular}{|l|}
\hline Ke y w o r d s \\
YVMV incidence, \\
Meteorological \\
parameters, Okra \\
varieties, Yield, \\
Summer season
\end{tabular}

A field experiment was conducted at Experimental farm, Department of Vegetable Research Centre, College of Agriculture, Vasantrao Naik Marathwada Krishi Vidyapeeth, Parbhani during summer season, 2015 to find out the effect of weather parameters on YVMV incidence of okra varieties in summer season. The experiment was conducted in randomized block design with four replications and six varieties $\left(\mathrm{V}_{1^{-}}\right.$Parbhani Kranti, $\mathrm{V}_{2^{-}}$ Parbhani OK-1, $\mathrm{V}_{3}$-Arka Anamika, $\mathrm{V}_{4}$-Arka Abhay, $\mathrm{V}_{5}$-VRO-6 (Kashi Pragati) and $\mathrm{V}_{6^{-}}$ Pusa Sawani). The results from the experiment revealed that incidence of YVMV was initiated in March and reached maximum in May. The correlation studies revealed that maximum and minimum temperature showed highly significant correlation $(p<0.01)$ with YVMV incidence on different okra varieties. Relative humidity (maximum) was significantly negative correlated with disease incidence. Evaporation has shown significant correlation with disease incidence only on $\mathrm{V}_{2}$ (Parbhani OK-1). Wind velocity showed significant positive correlation $(p<0.05)$ with varieties $\left(\mathrm{V}_{1}, \mathrm{~V}_{3}, \mathrm{~V}_{4}, \mathrm{~V}_{5}\right)$ while varieties $\mathrm{V}_{2}$ and $\mathrm{V}_{6}$ were positively correlated. Hence, the variety Parbhani Kranti can be grown in summer season as it showed less YVMV incidence and recorded higher productivity over other varieties.

\section{Introduction}

Okra [Abelmoschus esculentus (L.) Moench] commonly known as lady's finger or bhendi is most delicious vegetable relished world over, belongs to the family Malvaceae.

Okra fruits are rich in proteins (20-24\%) and their seeds contain 13-22\% edible oil (Sheikh et al., 2013). In general, okra is of African origin but the cultivated species i.e. Abelmoschus esculentus is probably of Indian origin (Dhankar et al., 2005). It is very important vegetable cultivated all over India particularly in the states of Andhra Pradesh, West Bengal, Jharkhand, Orissa, Uttar Pradesh, Madhya Pradesh, Karnataka, Gujarat and Maharashtra and constitutes $70 \%$ of the total fresh vegetable earnings, excluding onion (APEDA, 2000). In Maharashtra, bhendi is grown throughout the year providing continuous and good source of income to the farmers. In Maharashtra, it was cultivated in an area of 11.3 thousand hectares with annual production of 84.6 thousand tones and productivity of $7.5 \mathrm{t} \mathrm{ha}^{-1}$ (Anonymous, 2015). 
The productivity of okra has been low in recent times due to various reasons viz. inadequate use of fertilizers, irrigation and occurrence of various diseases and pests. Diseases are one of the major constraints for low productivity of bhendi (Das et al., 2011) and numerous fungal, bacterial, viral diseases have been reported in India. Amongst the viral diseases, Yellow vein mosaic virus is one of the important and of common occurrence wherever this crop is grown.

It was first reported in okra plants in 1924 in India (Kulkarni, 1924). The disease is characterized by alternate green and yellow patches, different degrees of chlorosis of leaves and in severe cases, the chlorosis may extend to the interveinal area and may result in complete yellowing of leaves. Fruits are dwarfed, malformed and turn yellow green. Fruit yield is greatly reduced (upto 96\%) if the crop is infected at an early stage (Pun and Doraiswamy, 1999).

The whitefly Bemisia tabaci (Genn.) species group is the insect vector. The whitefly vector reproduces to significant numbers during the summer season when it transmits the virus between okra plants. The causal agent is the single-stranded DNABhendi yellow vein mosaic virus (BYVMV), which is associated with a small satellite DNA $\beta$ component (Jose and Usha, 2003), both of which are required for infection. BYVMV belongs to the genus Begomovirus, family Geminiviridae (Fauquet and Stanley, 2005). Several YVMV resistant bhendi varieties have been released, but none have retained resistance for long (Usha, 2008). In recent times, many new varieties resistant to YVMV has been released but their resistance level is still of concern and is location specific. Hence, an experiment was planned with different resistant varieties with objective to work out the correlation between YVMV incidence on okra varieties and weather parameters in summer season.

\section{Materials and Methods}

An experiment was conducted at Experimental farm, Department of Vegetable Research Centre, College of Agriculture, Vasantrao Naik Marathawada Krishi Vidypeeth, Parbhani geographically situated at $19^{0} 16^{\text {, }}$ latitude and $76^{\circ} 47^{\prime}$ longitude, and at 409 meters above mean sea level. The experiment was carried out in randomized block design with four replications during summer season, 2015. Treatments consisted of six varieties i.e. $\mathrm{V}_{1}$ (Parbhani Kranti), $\mathrm{V}_{2}$ (Parbhani OK-1), $\mathrm{V}_{3}$ (Arka Anamika), $\mathrm{V}_{4}$ (Arka Abhay), $\mathrm{V}_{5}$ (VRO6 [Kashi Pragati]) and $\mathrm{V}_{6}$ (Pusa Sawani).

The experimental field was typical black cotton soil having medium fertility and good drainage. The total rainfall received during the crop growth period was $157.5 \mathrm{~mm}$ in 11 rainy days. During this period, maximum rainfall $(91.8 \mathrm{~mm})$ was received in the month of April and minimum rainfall $(24.8 \mathrm{~mm})$ was received in the month of May. The average maximum temperature was $37.2^{\circ} \mathrm{C}$ and minimum temperature was $19.7^{\circ} \mathrm{C}$. Mean morning and evening relative humidity was 69.7 per cent and 23.7 per cent, respectively. The mean bright sunshine hours was $8.98 \mathrm{hrs} \mathrm{day}^{-1}$, evaporation was $9.12 \mathrm{~mm} \mathrm{week}^{-1}$ and wind velocity was $5.08 \mathrm{~km} \mathrm{hr}^{-1}$ during the crop growth period. All the varieties were sown on $17^{\text {th }}$ February, 2015 with spacing $60 \times 30 \mathrm{~cm}$ in plots of $4.2 \times 3.9 \mathrm{~m}^{2}$. The sowing of seed was done by dibbling method. Recommended dose of fertilizers @ 80-40-40 NPK kg ha ${ }^{-1}$ was applied. Half dose of nitrogen and complete dose of phosphorus and potassium was applied at the time of sowing and remaining half dose of nitrogen was applied at 30 DAS. The fruits were picked from plots of $3.0 \times 2.7 \mathrm{~m}^{2}$ and first picking was done at 60 DAS and subsequent pickings were done at every third day, a total of 10 pickings were obtained. The test crop was harvested on $27^{\text {th }}$ May, 2015. The plot wise yield was converted 
per hectare and represented as $\mathrm{q} \mathrm{ha}^{-1}$. Recommended agronomic practices were followed to raise the crop.

\section{Observations recorded}

Pathological observations i.e. disease incidence of YVMV of different okra varieties were recorded from 30 DAS to harvest at every week interval with five randomly selected plants. Meteorological observations include rainfall $(\mathrm{mm})$, maximum and minimum temperature $\left({ }^{0} \mathrm{C}\right)$, maximum and minimum humidity (\%), bright sunshine hours (hrs day $\left.^{-1}\right)$, wind speed $\left(\mathrm{km} \mathrm{hr}{ }^{-1}\right)$ and evaporation $\left(\mathrm{mm} \mathrm{day}^{-1}\right)$ were recorded weekly.

\section{Data analysis}

The data pertaining to incidence of yellow vein mosaic virus was correlated with various weather factors. The correlations between weather parameters and disease incidence were studied. The relationship between fruit yield and per cent YVMV incidence was represented graphically.

\section{Results and Discussion}

\section{Pathological observations}

The YVMV disease evaluation was carried out at weekly intervals from 30 DAS to harvest. The per cent incidence of YVMV of different varieties was presented in Table 1. The YVMV incidence was initiated in March (30 DAS) and with the age of the crop the YVMV incidence increased progressively and reached maximum in the month of May (harvest stage) for all the varieties.

The YVMV incidence was increased for all the varieties from 75 DAS and that has resulted in low yields. During crop growth period, the mean per cent incidence of YVMV was found highest (28.1) in variety $\mathrm{V}_{6}$ (Pusa
Sawani). This variety is susceptible to YVMV and hence, recorded lowest yield. Similar findings of yellow vein mosaic disease on okra varieties were reported by Ajay et al., (2012). The lowest (7.8) per cent incidence of YVMV was observed in $\mathrm{V}_{1}$ (Parbhani Kranti). This variety is resistant to the viral disease and was found in accordance with findings of Bhagat et al., (2001).

\section{Relationship between okra fruit yield and YVMV incidence}

Significant negative correlation between fruit yield and per cent incidence of YVMV was observed $\left(\mathrm{R}^{2}=0.755, p<0.05\right)$ (Figure 1$)$. As the YVMV incidence is increased the fruit yield decreased. The similar findings of yellow vein mosaic disease on okra varieties were reported by Ajay et al., (2012).

\section{Correlation between weather parameters and YVMV incidence}

The correlation between the weather parameters and disease incidence of different okra varieties was presented in Table 2. All the varieties have shown negative correlation with rainfall for YVMV disease incidence. Maximum temperature showed highly significant correlation $(p<0.0 .1)$ with disease incidence of different okra varieties. Minimum temperature showed significant correlation $(p$ $<0.05)$ with disease incidence in all the varieties. As the temperature raised from April the disease incidence has also increased in all the varieties. Similar findings of temperature on disease incidence were observed by Muhammad et al., (2012). Relative humidity was negatively correlated with disease incidence and the level of significance $(p<$ 0.05 ) was observed for all the varieties except $\mathrm{V}_{2}$. Evaporation observed significant positive correlation $(p<0.05)$ with disease incidence only for $\mathrm{V}_{2}$ while for the rest of varieties the level of significance was not obtained. 
Table.1 Incidence of YVMV on different varieties of okra

\begin{tabular}{|c|c|c|c|c|c|c|c|}
\hline \multirow[t]{2}{*}{$\begin{array}{l}\text { MW } \\
\text { (no.) }\end{array}$} & \multirow[t]{2}{*}{$\begin{array}{l}\text { Month } \\
\text { period }\end{array}$} & $\begin{array}{c}\mathrm{V}_{1} \\
\text { (Parbhani } \\
\text { Kranti) }\end{array}$ & $\begin{array}{c}\mathrm{V}_{2} \\
\text { (Parbhani } \\
\text { OK-1) }\end{array}$ & $\begin{array}{c}V_{3} \text { (Arka } \\
\text { Anamika) }\end{array}$ & $\begin{array}{c}\mathrm{V}_{4} \\
\text { (Arka } \\
\text { Abhay) }\end{array}$ & $\begin{array}{c}\mathrm{V}_{5} \\
(\mathrm{VRO}- \\
6)\end{array}$ & $\begin{array}{c}\mathrm{V}_{6} \\
\text { (Pusa } \\
\text { Sawani) }\end{array}$ \\
\hline & & \multicolumn{6}{|c|}{ Per cent $(\%)$ incidence of YVMV } \\
\hline 12 & 19-25 March & 0.12 & 0.23 & 0.44 & 0.23 & 0.11 & 0.11 \\
\hline 13 & 26-01 April & 0.10 & 2.01 & 3.10 & 0.55 & 0.23 & 0.22 \\
\hline 14 & 02-08 April & 1.32 & 3.10 & 5.70 & 0.44 & 0.48 & 0.42 \\
\hline 15 & 09-15 April & 2.75 & 7.11 & 6.25 & 2.13 & 5.43 & 0.73 \\
\hline 16 & 16-22 April & 4.22 & 10.01 & 10.5 & 4.25 & 6.13 & 0.95 \\
\hline 17 & 23-29 April & 7.35 & 13.12 & 12.6 & 5.34 & 8.23 & 15.34 \\
\hline 18 & 30-06 Мay & 9.20 & 15.24 & 15.35 & 7.43 & 9.45 & 39.39 \\
\hline 19 & 07-13 May & 11.25 & 16.94 & 19.49 & 9.41 & 10.45 & 64.96 \\
\hline 20 & 14-20 May & 21.23 & 28.76 & 31.31 & 23.07 & 22.27 & 76.78 \\
\hline 21 & 21-27 May & 26.55 & 34.08 & 36.63 & 28.39 & 27.59 & 82.1 \\
\hline & Mean & 7.8 & 15.35 & 14.13 & 8.1 & 9.0 & 28.1 \\
\hline
\end{tabular}

Table.2 Correlation between different weather parameters and YVMV disease incidence of different okra varieties

\begin{tabular}{|c|c|c|c|c|c|c|}
\hline \multirow[t]{2}{*}{ Weather } & \multicolumn{6}{|c|}{ Varieties } \\
\hline & $\begin{array}{c}\mathrm{V}_{1} \\
\text { (Parbhani } \\
\text { kranti) }\end{array}$ & $\begin{array}{c}\mathrm{V}_{2} \\
\text { (Parbhani } \\
\text { OK-1) }\end{array}$ & $\begin{array}{c}\mathrm{V}_{3} \\
\text { (Arka } \\
\text { anamika) }\end{array}$ & $\begin{array}{c}\mathrm{V}_{4} \\
\text { (Arka } \\
\text { abhay) }\end{array}$ & $\begin{array}{c}\mathrm{V}_{5} \\
\text { (VRO- } \\
\mathbf{6})\end{array}$ & $\begin{array}{c}\text { V6 }_{6} \\
\text { (Pusa } \\
\text { sawani) }\end{array}$ \\
\hline Rainfall & -0.178 & -0.065 & -0.170 & -0.217 & -0.149 & -0.319 \\
\hline Temp max. & $0.933^{* *}$ & $0.966^{* *}$ & $0.965^{* *}$ & $0.955^{* *}$ & $0.949^{* *}$ & $0.950^{* *}$ \\
\hline Temp min. & $0.673^{*}$ & $0.736^{*}$ & $0.708^{*}$ & $0.681^{*}$ & $0.658^{*}$ & $0.711^{*}$ \\
\hline$\overline{\mathbf{R H}_{\max }}$ & $-0.702^{*}$ & -0.626 & $-0.694^{*}$ & $-0.718^{*}$ & $-0.649^{*}$ & $-0.793^{* *}$ \\
\hline $\mathbf{R H}_{\min }$ & -0.223 & -0.298 & -0.246 & -0.235 & -0.166 & -0.324 \\
\hline Evaporation & 0.617 & $0.632^{*}$ & 0.598 & 0.623 & 0.598 & 0.587 \\
\hline $\begin{array}{l}\text { Bright } \\
\text { sunshine } \\
\text { hours }\end{array}$ & 0.172 & 0.125 & 0.165 & 0.175 & 0.182 & 0.048 \\
\hline Wind speed & $0.749^{*}$ & 0.600 & $0.670^{*}$ & $0.741^{*}$ & $0.726^{*}$ & 0.614 \\
\hline
\end{tabular}

${ }^{*}$ significant at $5 \%,{ }^{* *}$ significant at $1 \%$ 
Fig.1 Relationship between okra fruit yield and per cent incidence of YVMV

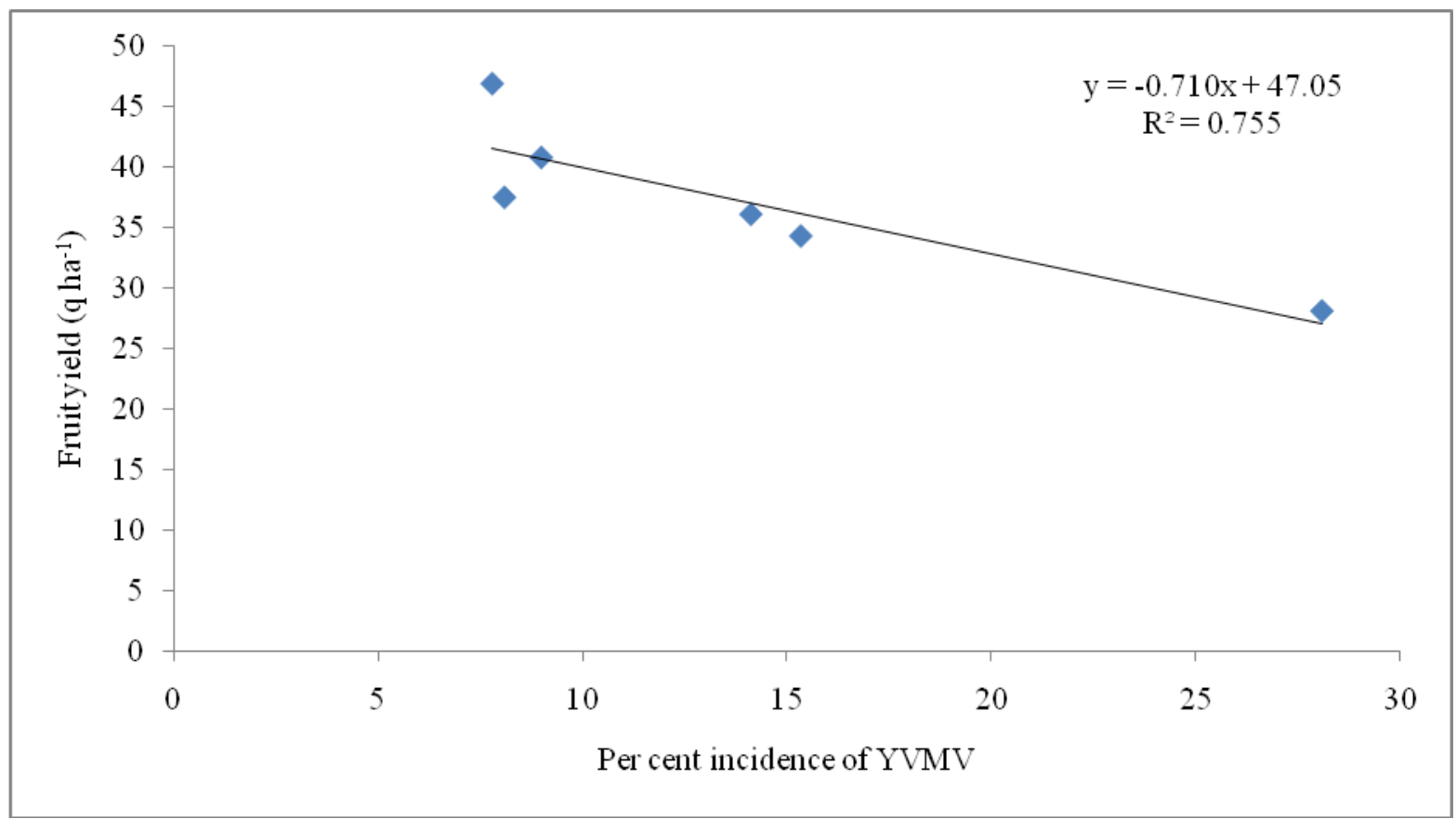

Wind velocity observed significant positive correlation $(p<0.05)$ with varieties $\left(\mathrm{V}_{1}, \mathrm{~V}_{3}\right.$, $\mathrm{V}_{4}$ and $\mathrm{V}_{5}$ ) while only positive correlation was observed for $V_{2}$ and $V_{6}$. Similar findings of weather parameters were reported by Das et al., (2011).

The present study suggests that the incidence of YVMV increased towards the harvest period (May). The positive correlation between weather parameters and YVMV disease incidence showed that disease incidence increased with increase in maximum and minimum temperature and maximum relative humidity. Hence, the variety Parbhani Kranti can be grown in summer season as it showed less YVMV incidence and recorded higher yield compared to other varieties.

\section{References}

Ajay, T., Singh, B., Singh, T.B., Sanval, S.K., and Pandey, S.D. 2012. Screening of okra varieties for resistance to yellow vein mosaic virus under field condition. Hort Flora Research Spectrum. 1(1): 92-93.

Anonymous. 2015. Horticultural Statistics at a Glance. Horticulture Statistics Division, Department of Agriculture, Cooperation and Farmers Welfare, Government of India, New Delhi.

APEDA. 2000. Agro-export statistics. Agriculture and Processed Food Export Development Agency, New Delhi, India.

Bhagat, A.P., Yadav, B.P., and Prasad, Y. 2001. Rate of dissemination of okra yellow vein mosaic virus disease in three cultivars of Okra. Indian Phytopathology. 54(4): 488-489.

Das, S., Pandey, V., Patel, H.R., and Patel, K.I. 2011. Effect of weather parameters on pest-disease of okra during summer season in middle Gujarat. Journal of Agrometeorology. 13(1): 38-42.

Dhankar, B.S., Mishra, J.P., and Bisht, I.S. 2005. Okra. In: Dhillon, B.S., Tyagi, R.K., Saxena, S., and Randhawa, G.J. 
(eds). Plant Genetic Resources: Horticultural Crops, pp 59-74. Narosa Publishing House, New Delhi, India.

Fauquet, C.M., and Stanley, J. 2005. Revising the way we conceive and name viruses below the species level: a review of Gemini virus taxonomy calls for new standardized isolate descriptors. Archives of Virology. 150: 2151-2179.

Jose, J., and Usha, R. 2003. Bhendi yellow vein mosaic disease in India is caused by association of a DNA $\beta$ satellite with a begomovirus. Virology. 305: 23102317.

Kulkarni, C.S. 1924. Mosaic and other related diseases of crops in the Bombay Presidency. Poona Agriculture College Magazine. 16.

Muhammad, E., Ali, M.I., Khan, M.A. Rashid, M., Javed, M.T., and Sajid, M. 2012. Epidemiology of Okra Yellow
Vein Mosaic Virus (OYVMV) and its Management through Tracer, Mycotal and Imidacloprid. American Journal of Plant Sciences. 3: 1741-1745.

Pun, K.B., and Doraiswamy, S. 1999. Effect of age of okra plants on susceptibility to Okra yellow vein mosaic virus. Indian Journal of Virology. 15: 57-58.

Sheikh, M.A., Safiuddin., Khan, Z., and Mahmood, I. 2013. Effect of bhendi yellow vein mosaic virus on yield components of okra plants. Journal of Plant Pathology. 95(2): 391-393.

Usha, R. 2008. Bhendi yellow vein mosaic virus. In: Rao, G.P., Kumar, P.L., and Holgun-Pena, R.J. (eds). Characterization, Diagnosis and Management of Plant Viruses. Vol. 3, pp. 387-392. Studium Press, Houston, Texas, USA.

\section{How to cite this article:}

Vadla Usha Sree, B.V. Asewar, A.T. Daunde, A.M. Khobragade and Perke, D.S. 2018. Influence of Weather Parameters on YVMV Incidence of Okra Varieties in Summer Season. Int.J.Curr.Microbiol.App.Sci. 7(03): 1305-1310. doi: https://doi.org/10.20546/ijcmas.2018.703.155 